\title{
HUBUNGAN ANTARA PENERIMAAN DIRI DENGAN PERILAKU AGRESI PADA REMAJA DI SEKOLAH MENENGAH PERTAMA
}

\author{
Olga Patricia Ritung1 dan Naomi Soetikno² \\ ${ }^{1}$ Fakultas Psikologi, Universitas Tarumanagara \\ Email: olgap.ritung@gmail.com \\ ${ }^{2}$ Fakultas Psikologi, Universitas Tarumanagara \\ Email: naomi_wb@yahoo.com
}

\begin{abstract}
ABSTRAK
Tujuan penelitian ini adalah untuk mengetahui hubungan antara penerimaan diri dengan perilaku agresi pada remaja di sekolah menengah pertama. Perilaku agresi merupakan suatu perilaku yang disadari atau disengaja oleh seseorang yang dilakukan dalam bentuk verbal maupun fisik serta bertujuan untuk menyakiti atau merugikan orang lain sehingga menyebabkan rasa sakit dan trauma, baik secara fisik maupun psikis. Penerimaan diri merupakan gambaran diri seseorang secara positif dan mengakui kelebihan maupun kekurangannya, serta memahami keinginan dan kemauan dalam dirinya dalam bentuk pandangan yang objektif. Subyek penelitian adalah remaja awal berusia 12 sampai dengan 15 tahun. Penelitian dilakukan pada 370 subyek yang bersekolah di SMP yang berada di wilayah Jabotabek. Setelah dilakukan uji normalitas dan didapatkan distribusi data kedua variabel, baik penerimaan diri maupun perilaku agresi tidak normal maka untuk mencari ada atau tidaknya hubungan tersebut penelitian ini menggunakan metode uji korelasi Chi Square. Hasil analisis data menggunakan uji korelasi Chi Square menunjukkan bahwa agresi emosional/hostile memiliki nilai Chi Square $=611.440$ dan p $=.000$. Agresi fisik memiliki nilai Chi Square $=1266.656$ dan $p=.000$. Hasil penelitian diperoleh terdapat hubungan positif antara penerimaan diri dengan perilaku agresi, baik indikator agresi emosional/hostile dan agresi fisik pada remaja.
\end{abstract}

Kata Kunci: Perilaku agresi, penerimaan diri, dan remaja.

\section{PENDAHULUAN \\ Latar Belakang}

Saat ini, pada banyak sekolah, masalah umumnya adalah penyalahgunaan obat-obatan, penyalahgunaan alkohol, hamil, pemerkosaan, perampokan dan penyerangan, kekerasan antargeng, pembakaran, pembunuhan, perusakan, penyakit kelamin, bunuh diri, pemboman, ketidakhadiran, dan aborsi (Tindall \& Black, 2009). Di Indonesia terdapat beberapa kasus anak yang berhadapan dengan hukum. Sepanjang tahun 2011, Komnas Anak menerima 1.851 pengaduan anak yang berhadapan dengan hukum (anak sebagai pelaku) yang diajukan ke pengadilan. Hampir 52 persen dari angka tersebut adalah kasus pencurian diikuti dengan kasus kekerasan, perkosaan, narkoba, perjudian, serta penganiayaan. Data ini diperkuat oleh data anak yang tersebar di 16 Lapas di Indonesia (data Kementrian Hukum dan HAM 2010) dan ditemukan 6.505 anak yang berhadapan dengan hukum diajukan ke pengadilan, serta 4.622 anak di antaranya saat ini mendekam di penjara ("Catatan Akhir Tahun 2011 Komisi Nasional Perlindungan Anak", 2011).

Families and Work Institute and The Colorado trust yang dikutip dari Soetjiningsih (dalam Rina, 2011), melakukan penelitian dengan mengumpulkan data-data dari remaja mengenai penyebab mengapa mereka melakukan tindak kekerasan. Sebagian besar dari mereka mengaku mengalami kekerasan emosional dan fisik. 575 remaja merasakan dirinya diejek, diolok-olok atau dibicarakan hal-hal negatif oleh orang lain. Pengalaman ini sering dialami mereka dilingkungan sekolahnya sehingga hampir sekitar 90\% kekerasan terjadi di sekolah. Sedangkan sekitar $46 \%$ remaja pernah dipukuli atau dilukai. Hanya masing-masing 85 yang pernah diserang dengan senjata dan mengalami perkosaan seksual. Ternyata $35 \%$ remaja yang mengalami kekerasan 
dengan senjata atau serangan lainnya, akan melakukan tindak kekerasan juga terhadap orang lain.

Menurut Sarwono (2012), masa remaja memasuki tahap pembebasan kehendak dari kekuatankekuatan dari dalam diri sendiri maupun dari lingkungannya (misalnya dari orangtuanya) yang selama ini mendominasinya. Menurut Richmond dan Sklansky (dalam Sarwono, 2012) inti dari tugas perkembangan seseorang dalam periode remaja awal dan menengah adalah memperjuangkan kebebasan.

Mencapai kematangan emosional merupakan tugas perkembangan yang sangat sulit bagi remaja (Yusuf, 2000). Remaja awal mungkin lebih banyak merajuk, tidak tahu bagaimana harus mengekspresikan perasaan mereka secara memadai dan dengan sedikit atau tanpa provokasi, mereka mungkin marah pada orangtua atau saudara kandung mereka, memproyeksikan perasaan tidak menyenangkan mereka kepada orang lain (Santrock, 2007). Dalam menghadapi ketidaknyamanan emosional tersebut, tidak sedikit remaja yang reaksinya secara defensif, sebagai upaya untuk melindungi kelemahan dirinya sehingga reaksi itu tampil dalam tingkah laku malasuai (maladjusment), seperti (1) agresif: melawan, keras kepala, bertengkar, berkelahi, dan senang menggangu; dan (2) melarikan diri dari kenyataan: melamun, pendiam, senang menyenangkan diri, dan meminum minuman keras atau obat-obat terlarang (Yusuf, 2000).

Pada saat ini remaja mempunyai resiko tinggi terhadap gangguan tingkah laku, kenakalan remaja dan terjadinya kekerasan baik sebagai korban maupun sebagai pelaku dan tindak kekerasan (Soetjiningsih, dalam Rina, 2011). Salah satu bentuk kenakalan remaja yang ada pada saat ini adalah perkelahian massal atau yang popular di kalangan pelajar disebut dengan istilah tawuran. Keterlibatan tawuran pada pelajar juga adanya takut akan penolakan sosial, yakni perasaan tidak disukai teman sebayanya (Kurniawan \& Rois, n.d.). Data resmi KPAI diperoleh dari pengolahan data primer berupa pengaduan langsung, data lembaga mitra perlindungan anak, serta pemantauan kasus di media massa, sehingga diperoleh data tawuran Jabodetabek, sebagai berikut: pada tahun 2010 terdapat 102 kasus dengan 54 luka ringan, 31 luka berat, dan 17 meninggal dunia; pada tahun 2011 terdapai 96 kasus dengan 62 luka ringan, 22 luka berat, dan 12 meninggal dunia; dan yang terakhir pada tahun 2012 terdapat 103 kasus dengan 48 luka ringan, 39 luka berat, dan 17 meninggal dunia (Putri, 2012). Sedangkan tingkat pendidikan pelaku tawuran terdiri dari, SD 2 kasus, SMP 19 kasus, dan tingkat SMU/SMK 28 kasus (Tim KPAI, 2013).

Geng-geng remaja terdiri atas remaja-remaja yang ditolak secara sosial oleh teman-teman sebaya mereka yang kurang agresif, sehingga geng-geng tersebut dianggap menarik bagi individuindividu yang memiliki agresivitas tinggi dan bertanggung jawab atas tingginya proporsi agresi remaja, termasuk perkelahian antargeng (Krahe, 2005). Perilaku agresi ini yang membuat segolongan orang menganggap remaja sebagai sekelompok individu yang sering melakukan pelanggaran, menyusahkan orangtua maupun orang lain di sekitarnya (Rumini \& Sundari, 2004). Ketidakjelasan terhadap peran atau potensi diri membuat remaja masih mencari pegangan yang dapat digunakan sebagai acuan agar eksistensinya diakui oleh lingkungan (Kurniawan \& Rois, n.d.).

Sebagaimana yang dikemukakan oleh Havighurt (dalam Hartati, Erlamsyah, \& Syahniar, 2013) bahwa remaja yang mencapai tugas perkembangannya mampu menerima keadaan fisiknya dan mempergunakannya secara efektif. Sullivan (dalam Pardede, 2008) menjelaskan bahwa jika individu diterima orang lain, diterima dan disenangi karena keadaannya, maka individu akan bersikap menghormati dan menerima diri sendiri. Salah satu cara untuk mencapai tujuan hidup 
adalah dengan cara lebih mengenal diri sendiri, yaitu apakah kekuatan-kekuatan diri dan apakah kelemahan-kelemahan diri, sehingga dengan demikian menyadari 'siapa saya' dan 'saya ingin menjadi siapa', merupakan dasar berpijak dalam menghadapi masalah yang kompleks (Handayani, Ratnawati, \& Helmi, 1998).

Penerimaan diri berkaitan dengan konsep diri yang positif. Seseorang dengan konsep diri yang positif dapat memahami dan menerima fakta-fakta yang begitu berbeda dengan dirinya, orang dapat menyesuaikan diri dengan seluruh pengalaman mentalnya sehingga evaluasi tentang dirinya juga positif (Handayani et al., 1998). Konsep diri stabil juga merupakan faktor yang mempengaruhi penerimaan diri pada seseorang, individu yang tidak memiliki konsep diri yang stabil, akan sulit menunjukkan pada orang lain siapa ia sebenarnya, sebab ia sendiri ambivalen terhadap dirinya (Hurlock, dalam Ardilla \& Herdiana, 2013).

Menurut sebagian remaja sendiri mereka merasa sebagai individu-individu yang dikesampingkan, diacuhkan, karena orang dewasa lebih memperhatikan generasi anak-anak kecil yang sangat butuh perhatian dan pemeliharaan. Seolah-olah remaja sudah dapat mengurusi dirinya sendiri. Remaja masih ingin/mendambakan kasih sayang seperti masa lalu (Rumini \& Sundari, 2004). Hal ini menyatakan sebagian remaja memiliki penerimaan diri yang rendah, di mana mereka memandang diri mereka dipengaruhi oleh situasi-situasi yang membuat frustrasi yang berasal dari orang dewasa atau lingkungan sekitar.

Kelompok terbesar tampaknya terdiri dari anak muda yang bermasalah dan memiliki konflik secara emosional yang terasingkan, marah, dan depresi. Mereka merasa diperlakukan tidak adil oleh orang lain, kesepian, dan terisolasi (Tindall \& Black, 2009). Banyak remaja yang tersakiti oleh pengalaman melukai dengan cepat untuk melakukan serangan dengan terlebih dahulu menyangkal rasa sakit mereka, dan kemudian mencoba untuk melepaskannya dengan cara menertawakan, mengejek, mencaci-maki, menggoda, mencela dan menghina teman sebaya mereka yang mudah diserang (Brill, 2000). Berdasarkan berbagai uraian tersebut, penulis ingin melihat dan mengetahui hubungan antara penerimaan diri dengan perilaku agresi pada remaja, khususnya remaja awal yang berada di bangku Sekolah Menengah Pertama.

\section{Rumusan Masalah}

Apakah ada hubungan antara penerimaan diri dengan perilaku agresi pada remaja di Sekolah Menengah Pertama?

\section{METODE PENELITIAN}

\section{Subjek Penelitian}

Subyek penelitian ini adalah remaja awal berjenis kelamin pria dan wanita yang berada pada rentang usia 12 sampai dengan 15 tahun. Subyek merupakan siswa dan siswi dari Sekolah Menengah Pertama yang berada di wilayah Jabotabek. Sampel yang digunakan merupakan siswa dan siswi yang saat ini sedang duduk di bangku Sekolah Menengah Pertama kelas dua (kelas delapan) dengan ciri-ciri kelas yang memiliki perilaku agresi yang cukup tinggi. Ciri-ciri kelas tersebut didapatkan berdasarkan uraian dari guru-guru di sekolah yang mengatakan bahwa kelas tersebut sering mendapatkan terguran dan peringatan karena bermasalah, serta siswa-siswinya sering bertengkar satu dengan yang lainnya. Jumlah subyek yang digunakan dalam penelitian ini adalah 370 subyek. 


\section{Metode Pengumpulan Data}

Pengambilan sampel yang akan dilakukan menggunakan teknik sampling, yaitu nonprobability sampling, yaitu purposive sampling. Alat ukur yang digunakan adalah skala perilaku agresi yang dikembangkan dari teori Berkowitz (1995) dan beberapa teori tambahan dari Taylor, Peplau, \& Sears (2006), dan skala penerimaan diri yang dipinjam melalui Bagian Riset dan Pengukuran Fakultas Psikologi Universitas Tarumanagara yang dikembangkan dari teori Ryff.

\section{Metode Analisa Data}

Pengolahan dan teknik analisis data menggunakan alat bantu komputer dengan program Stastistical Product and Service Solution (SPSS) realese 18.00. Data yang diperoleh dianalisis secara kuantitatif. Pengolahan data penelitian ini bertujuan untuk memberikan hubungan antara penerimaan diri dengan perilaku agresi pada remaja di Sekolah Menengah Pertama. Teknik analisis data yang digunakan adalah menggunakan uji hubungan (korelasi) antara penerimaan diri dan perilaku agresi. Pengujian hipotesis yang dilakukan menggunakan uji korelasi Chi Square dikarenakan uji normalitas data kedua variabel, baik penerimaan diri maupun perilaku agresi tidak normal dan bentuk skala kedua variabel berbeda satu dengan yang lainnya.

\section{HASIL DAN PEMBAHASAN}

Berdasarkan hasil uji korelasi dengan menggunakan Chi Square antara variabel penerimaan diri dengan variabel perilaku agresi, dimana perilaku agresi dibagi menjadi 6 indikator, yaitu agresi instrumental, agresi emosional/hostile, agresi fisik, agresi verbal, agresi prososial, dan agresi antisosial, maka didapatkan untuk dimensi tujuan, hasil perhitungan indikator agresi instrumental menunjukkan bahwa nilai Chi Square $=531.905$ dan signifikansi $(p)=.906>.05$. Dengan demikian tidak terdapat hubungan antara penerimaan diri dan indikator agresi instrumental. Sedangkan hasil perhitungan indikator agresi emosional/hostile menunjukkan bahwa nilai $C h i$ Square $=611.440$ dan signifikansi $(p)=.000<.05$. Dengan demikian terdapat hubungan yang signifikan antara penerimaan diri dan indikator agresi emosional/hostile. Dalam dimensi sifat, hasil perhitungan indikator agresi fisik menunjukkan bahwa nilai Chi Square $=1266.656$ dan signifikansi $(p)=.000<.05$. Dengan demikian terdapat hubungan yang signifikan antara penerimaan diri dan indikator agresi fisik. Sedangkan hasil perhitungan indikator agresi verbal menunjukkan bahwa nilai Chi Square $=978.866$ dan signifikansi $(p)=.739>.05$. Dengan demikian tidak terdapat hubungan antara penerimaan diri dan indikator agresi verbal. Terakhir dalam dimensi sikap, hasil perhitungan indikator agresi prososial menunjukkan bahwa nilai Chi Square $=184.471$ dan signifikansi $(p)=.639>.05$. Dengan demikian tidak terdapat hubungan antara penerimaan diri dan indikator agresi prososial. Untuk hasil perhitungan indikator agresi antisosial menunjukkan bahwa nilai Chi Square $=673.204$ dan signifikansi $(p)=.48>.05$. Dengan demikian tidak terdapat hubungan antara penerimaan diri dan indikator agresi antisosial.

Hasil uji korelasi dari perilaku agresi jika ditinjau dari tempat tinggal subyek. Setelah dilakukan uji korelasi dengan teknik Contingency Coefficient untuk dimensi tujuan, hasil perhitungan indikator agresi instrumental menunjukkan bahwa value $=.210$ dan signifikansi $(\mathrm{p})=1.000>$ .05. Dengan demikian tidak terdapat hubungan antara indikator agresi instrumental dan tempat tinggal subyek. Untuk hasil perhitungan indikator agresi emosional/hostile menunjukkan bahwa value $=.312$ dan signifikansi $(p)=.305>.05$. Dengan demikian tidak terdapat hubungan antara indikator agresi emosional/hostile dan tempat tinggal subyek. Dalam dimensi sifat, hasil perhitungan indikator agresi fisik menunjukkan bahwa nilai value $=.287$ dan signifikansi $(p)=$ $1.000>.05$. Dengan demikian tidak terdapat hubungan antara indikator agresi fisik dan tempat tinggal subyek. Untuk hasil perhitungan indikator agresi verbal menunjukkan bahwa value $=$ 
.345 dan signifikansi $(p)=.981>.05$. Dengan demikian tidak terdapat hubungan antara indikator agresi verbal dan tempat tinggal subyek. Untuk dimensi sikap, hasil perhitungan indikator agresi prososial menunjukkan bahwa value $=.177$ dan signifikansi $(p)=.619>.05$. Dengan demikian tidak terdapat hubungan antara indikator agresi prososial dan tempat tinggal subyek. Dan untuk hasil perhitungan indikator agresi antisosial menunjukkan bahwa value $=.264$ dan signifikansi $(p)=.992>.05$. Dengan demikian tidak terdapat hubungan antara indikator agresi antisosial dan tempat tinggal subyek.

Hasil uji korelasi dari penerimaan diri jika ditinjau dari tempat tinggal subyek. Setelah dilakukan uji korelasi dengan teknik Chi Square untuk penerimaan diri, hasil perhitungan menunjukkan bahwa nilai Chi Square $=154.084$ dan signifikansi $(p)=.268>.05$. Dengan demikian tidak terdapat hubungan antara penerimaan diri dan tempat tinggal subyek, atau dengan kata lain penerimaan subyek baik yang tinggal bersama orangtua, bersama keluarga, sewa/kontrak, dan lain-lain sama saja.

\section{Pembahasan}

Hasil analisis data menunjukkan adanya hubungan positif dan signifikan antara perilaku agresi dan penerimaan diri pada remaja. Hubungan positif dan signifikan ini hanya ditemukan dalam indikator agresi emosional/hostile dan agresi fisik. Hal ini menunjukkan bahwa semakin sering remaja melakukan perilaku agresi, baik agresi emosional/hostile maupun fisik, maka akan menyebabkan semakin besar kemungkinan remaja menerima dirinya. Begitu pula sebaliknya, semakin jarang remaja melakukan perilaku agresi tersebut maka semakin kecil kemungkinan remaja dapat menerima dirinya sendiri.

Hasil penelitian ini bertentangan dengan penyataan dari Hjelle dan Ziegler (1981) yang menyatakan bahwa penerimaan diri sebagai toleransi individual pada kejadian-kejadian yang membuat frustrasi atau menjengkelkan serta pengenalan dari kekuatan pribadi diri mereka. Hal serupa juga dikemukakan oleh Ryff dan Singer (dalam Hidalgo, et. al., 2010) yang mengatakan bahwa kesejahteraan lebih dari perasaan bahagia atau puas terhadap kehidupan secara sederhana, tetapi juga bukan hanya tidak adanya emosi atau pengalaman negatif yang diartikan sebagai hidup dengan baik. Melainkan perlu memiliki persepsi yang kaya akan pengalaman ini dan sukses mengatur tantangan dan kesulitan yang mungkin timbul. Akan tetapi, beberapa teori mendukung hasil penelitian yang diperoleh. Perkembangan kognitif masa remaja awal yang belum berkembang secara sempurna dapat membuat individu merasa puas akan keadaan dirinya saat ini. Hal ini didukung oleh pendapat Rumini dan Sundari (2004) yang menyatakan bahwa pada umumnya masa remaja awal sifat berfikirnya belum mencapai kematangan. Oleh karena itu, dari hasil penelitian didapatkan bahwa partisipan memiliki agresi fisik yang tinggi dikarenakan mereka belum mampu berpikir panjang sebelum mengambil tindakan. Pada umumnya, masa remaja (termasuk remaja awal) merupakan masa transisi antara masa kanakkanak dan dewasa yang melibatkan perubahan fisik, kognitif, dan psikososial (Papalia, et al., 2009). Pada masa ini, remaja dapat dikatakan merasakan pertentangan yang terjadi di dalam dirinya. Oleh sebab itu, hasil penelitian menunjukkan selain agresi fisik, agresi emosional/hostile juga tinggi dikarenakan pada masa ini remaja masih bersikap impulsif dan ambivalen. Papalia, et al. (2009) juga mengatakan remaja merasakan ketegangan antara ketergantungan pada orangtua mereka dan kebutuhan untuk melepaskan diri. Agresi emosional/hostile ini merupakan bentuk dari adanya pemberontakan dalam diri remaja untuk lepas dari tuntutan orangtua atau orang dewasa lainnya.

Berdasarkan uraian di atas, hal-hal tersebut dapat memicu remaja yang melakukan agresi merasa puas terhadap perilaku tersebut. Hal ini didukung dengan pendapat Chaplin (2008) yang 
mengatakan bahwa penerimaan diri sebagai sikap yang pada dasarnya merasa puas dengan diri sendiri, kualitas-kualitas dan bakat-bakat sendiri, dan pengakuan akan keterbatasan-keterbatasan sendiri. Acapkali terlihat remaja yang belum bisa berpikir tentang tujuan dalam jangka panjang (Gunarsa \& Gunarsa, 1995). Ada juga remaja yang belum bisa menangguhkan kesenangan sementara demi tujuan yang lebih berarti. Hal ini memperlihatkan bahwa pola pikir remaja menggambarkan kepuasan akan situasi yang dialami saat ini tanpa memikirkan tujuan jangka panjang. Sehingga dapat dikatakan bahwa remaja melakukan penerimaan diri pada situasi atau kondisi yang terjadi saat ini. Salah satu hal yang mendukung hasil penelitian adalah adanya sumber terjadinya perilaku agresi seperti frustrasi yang dapat meringankan emosi negatif (Taylor, et. al., 2006). Individu yang mengalami frustrasi bertindak agresi untuk mengurangi emosi negatif tersebut, sehingga perilaku agresi yang meningkat merupakan wujud emosi positif dalam diri. Hal ini berkaitan dengan pernyataan Krahe (2013) yang menyatakan bahwa pengalaman frustrasi mengaktifkan hasrat untuk mengembalikan jalur menuju pencapaian tujuan, dan perilaku agresif dihasilkan dari dorongan untuk menghapus sumber gangguan. Beberapa pernyataan tersebut mendukung hasil penelitian yang didapatkan di mana penerimaan diri subyek yang melakukan agresi cukup tinggi. Berdasarkan tahapan penerimaan diri Germer (2009) yang terdiri dari aversion (keseganan), curiosity (keingintahuan), toleransi, allowing (memperbolehkan), dan friendship (pertemanan), subyek penelitian yang memiliki penerimaan diri yang cukup tinggi telah mencapai tahap friendship (pertemanan). Subyek penelitian melakukan penerimaan diri yang salah dikarenakan subyek telah bertoleransi dengan perilaku agresi yang terjadi di lingkungan sekitarnya dan memperbolehkan hal tersebut terjadi. Sehingga pada akhirnya subyek melakukan pertemanan dengan perilaku agresi yang dilakukan.

Hasil analisis hubungan antara indikator-indikator dalam perilaku agresi dengan tempat tinggal subyek dan hubungan antara penerimaan diri dengan tempat tinggal subyek diperoleh bahwa tidak ada hubungan dalam indikator-indikator perilaku agresi, baik agresi instrumental, emosional/hostile, fisik, verbal, prososial, dan antisosial terhadap tempat tinggal subyek, serta tidak ada hubungan antara penerimaan diri terhadap tempat tinggal subyek. Hal tersebut menggambarkan bahwa subyek yang tinggal bersama orangtua, bersama keluarga (seperti kakek/nenek, om/tante), sewa/kontrak, maupun lain-lainnya memiliki penerimaan diri yang sama.

Penelitian ini memiliki beberapa keterbatasan, yaitu kondisi lingkungan kelas yang kurang kondusif sehingga saat mengisi kuesioner subyek penelitian kurang fokus dan serius dalam menjawab, serta subyek juga lebih banyak berbicara dengan teman sekelasnya. Hal ini dapat mempengaruhi jawaban yang diberikan subyek sehingga hasil yang didapatkan menunjukkan tingkat agresi yang rendah padahal penelitian dilakukan di sekolah-sekolah dengan tingkat agresi yang cukup tinggi.

\section{KESIMPULAN DAN SARAN}

\section{Simpulan}

Berdasarkan analisis data yang telah dilakukan mengenai hubungan antara penerimaan diri dengan perilaku agresi pada remaja di Sekolah Menengah Pertama maka diperoleh hasil bahwa adanya hubungan positif dan signifikan antara penerimaan diri dan perilaku agresi pada remaja. Hubungan positif dan signifikan ini hanya ditemukan dalam indikator agresi emosional/hostile dan agresi fisik. Hal ini menunjukkan bahwa semakin sering remaja melakukan perilaku agresi, baik agresi emosional/hostile maupun fisik, maka akan menyebabkan semakin besar kemungkinan remaja menerima dirinya. Begitu pula sebaliknya, semakin jarang remaja 
melakukan perilaku agresi tersebut maka semakin kecil kemungkinan remaja dapat menerima dirinya sendiri.

\section{Saran}

Saran diberikan kepada instansi yang bergerak dalam bidang pendidikan, seperti kepala sekolah, guru, serta staf yang ada di dalam lingkup sekolah untuk mengembangkan penerimaan diri yang baik bagi siswa dan siswi. Pengembangan penerimaan diri dapat dilakukan dengan diterapkannya pembelajaran mengenai pembangunan karakter (character building) di sekolah untuk menanamkan hal-hal positif dalam diri siswa dan siswi. Selain itu, pihak sekolah juga sebaiknya memperhatikan kondisi ruangan kelas dengan menciptakan suasana yang kondusif untuk melakukan proses belajar-mengajar agar siswa dan siswi mampu berkonsentrasi dan fokus dalam mengikuti proses pembelajaran yang berlangsung sehingga perilaku agresi yang dapat terjadi di dalam kelas berkurang.

Saran berikutnya juga ditujukan bagi para orangtua untuk dapat memahami kondisi psikis anak sehingga kebutuhannya dapat terpenuhi dan anak terbebas dari perilaku agresi yang mungkin terjadi. Penanaman nilai dan moral yang baik dapat diajarkan oleh orangtua di rumah agar anak mampu membentuk penerimaan diri yang baik sehingga di saat anak berada di luar lingkungan keluarga, anak dapat menjaga tingkah laku dengan baik dan mampu mengontrol perilaku negatif yang dapat merugikan orang lain. Penulis juga menyarankan bagi para orangtua untuk mengembangkan bakat-bakat dalam diri anak sehingga mereka mampu menggunakan kelebihankelebihan dalam dirinya dan mengatasi kekurangan-kekurangan yang ada. Pengembangan bakat ini mampu menunjang anak untuk menerima dirinya secara positif.

Saran bagi penelitian selanjutnya adalah untuk mengembangkan penelitian mengenai penerimaan diri pada remaja yang melakukan perilaku agresi. Penulis juga menyarankan untuk mengontrol ruangan kelas saat proses pengambilan data berlangsung sehingga subyek dapat fokus dalam memberikan jawaban.

\section{Ucapan Terima Kasih (Acknowledgement)}

Penulis mengucapkan terima kasih kepada Kepala Sekolah di SMP-SMP wilayah Jabotabek, seluruh siswa dan siswi yang telah bersedia meluangkan waktunya. Seluruh tulisan dalam jurnal ini sepenuhnya menjadi tanggung jawab penulis.

\section{REFERENSI}

Ardilla, F., \& Herdiana, I. (2013). Penerimaan diri pada narapidana wanita. Jurnal Psikologi Kepribadian dan Sosial, 2(1), 1-7.

Berkowitz, L. (1995). Agresi 1: Sebab dan akibatnya. (H. W. Susiatni, Terj.). Jakarta: Pustaka Binaman Pressindo.

Brill, R. R. (2000). Emotional honesty \& self-acceptance: Education strategies for preventing violence. United States, US: Xlibris.

Chaplin, J. P. (2008). Kamus lengkap psikologi. (K. Kartono, Terj.). Jakarta: RajaGrafindo Persada.

Germer, C. K. (2009). The mindful path to self-compassion: Freeing yourself from destructive thoughts and emotions. New York, NY: The Guilford Press.

Gunarsa, S. D., \& Gunarsa, Y. S. D. (1995). Psikologi perkembangan anak dan remaja. Jakarta: BPK Gunung Mulia. 
Handayani, M. M., Ratnawati, S., \& Helmi, A. F. (1998). Efektifitas pelatihan pengenalan diri terhadap peningkatan penerimaan diri dan harga diri. Jurnal Psikologi, (2), 47-55.

Hartati, J., Erlamsyah, \& Syahniar. (2013). Hubungan antara perlakuan orangtua dengan penerimaan diri siswa. Jurnal Ilmiah Konseling, 2(1), 338-346.

Hidalgo, J. L., Bravo, B. N., Martinez, I. P., Pretel, F. A., Postigo, J. M. L., \& Rabadan, F. E. (2010). Psychological well-being assessment tools and related factors. InI. E. Wells (Ed.), Psychological well-being (pp. 77-113). New York, NY: Nova Science Publishers.

Hjelle, L. A., \& Ziegler, D. J. (1981). Personality theories: Basic assumptions, research, and application (2nd ed.). Singapore: McGraw-Hill.

Komisi Nasional Perlindungan Anak. (2011, Desember 20). Catatan akhir tahun 2011 komisi nasional perlindungan anak [Web log post]. Diunduh dari http://komnaspa.wordpress.com/2011/12/21/catatan-akhir-tahun-2011-komisi-nasionalperlindungan-anak/

Kurniawan, S., \& Rois, A. M. M. (n.d.). Tawuran, prasangka terhadap kelompok siswa sekolah lain, serta konformitas pada kelompok teman sebaya. Proyeksi, 4(2), 85-94.

Krahe, B. (2013). The social psychology of aggression (2nd ed.). New York, NY: Psychology Press.

Papalia, D. E., Olds, S. W., \& Feldman, R. D. (2009). Human development (11th ed.). New York, NY: McGraw-Hill.

Pardede, Y. O. K. (2008). Konsep diri anak jalanan usia remaja. Jurnal Psikologi, 1(2), 146-151.

Putri, A. (2012, September). Setahun, 17 pelajar tewas karena tawuran. Tempo. Diambil dari http://www.tempo.co/read/news/2012/09/27/064432335/Setahun-17-Pelajar-TewasKarena-Tawuran

Rina. (2011). Faktor-faktor yang melatarbelakangi perilaku agresif pada remaja kelas II, III di SMP Pahlawan Toha Bandung 18 September 2006 - 05 Januari 2007. Jurnal Kesehatan Prima, 3(2), 14-24.

Rumini, S., \& Sundari, S. (2004). Perkembangan anak dan remaja. Jakarta: Rineka Cipta.

Santrock, J. W. (2007). Adolescence (12th). New York, NY: McGraw-Hill.

Sarwono, S. W. (2012). Psikologi remaja. Jakarta: RajaGrafindo Persada.

Taylor, S. E., Peplau, L. A., \& Sears, D. O. (2006). Social psychology (12th ed.). New Jersey, NJ: Pearson Education.

Tim KPAI. (2013, 6 Juni). KPAI: Segera bentuk sekolah ramah anak. Komisi Perlindungan Anak Indonesia. Diunduh dari http://www.kpai.go.id/aksi/kpai-segera-bentuk-sekolah-ramahanak/

Tindall, J. A., \& Black, D. R. (2009). Peer programs: An in-depth look at peer programs: Planning, Implementation, and administration (2nd ed.). New York, NY: Taylor and Francis Group.

Yusuf, S. (2000). Psikologi perkembangan anak dan remaja. Bandung: Remaja Rosdakarya. 